\title{
GENETIC LINKAGE MAPS OF CHICKEN CHROMOSOMES 6, 7, 8, 11 AND 13 FROM A BRAZILIAN RESOURCE POPULATION
}

\author{
Marcel Ambo ${ }^{1}$; Raquel de Lello Rocha Campos ${ }^{1}$; Ana Sílvia Meira Tavares Moura ${ }^{4}$; Clarissa \\ Boschiero $^{4}$; Millor Fernandes do Rosário ${ }^{2}$; Mônica Corrêa Ledurr ${ }^{5}$; Kátia Nones ${ }^{6}$; Luiz Lehmann \\ Coutinho $^{3 *}$ \\ ${ }_{2}^{1}$ USP/ESALQ - Programa de Pós-Graduação em Ciência Animal e Pastagens. \\ ${ }^{2}$ USP/ESALQ - Programa de Pós-Graduação em Genética e Melhoramento de Plantas. \\ ${ }^{3}$ USP/ESALQ - Depto. de Zootecnia, C.P. 09 - 13418-900 - Piracicaba, SP - Brasil. \\ ${ }_{5}^{4}$ UNESP/FMVZ - Depto. de Produção Animal - 18618-000 - Botucatu, SP - Brasil. \\ ${ }^{5}$ Embrapa Suínos e Aves, C.P. 21 - 89700 - 000 - Concórdia, SC - Brasil. \\ ${ }^{6}$ Crop \& Food Research, Private Bag 4704 - Christchurch 8140 - New Zealand. \\ *Corresponding author <llcoutin@esalq.usp.br>
}

\begin{abstract}
A linkage map is essential not only for quantitative trait loci (QTL) mapping, but also for the organization and location of genes along the chromosomes. The present study is part of a project whose major objective is, besides from construction the linkage maps, the whole genome scan for mapping QTL for performance traits in the Brazilian experimental chicken population. Linkage maps of chicken chromosomes 6 to 8,11 and 13 were constructed based on this population. The population was developed from two generations of crossbreeding between a broiler and a layer line. Fifty-one microsatellite markers were tested, from which 28 were informative: 4, 8, 7, 4 and 5 for chromosomes 6 , $7,8,11$ and 13, respectively. A SNP located in the leptin receptor gene was included for chromosome 8. Ten parental, $8 \mathrm{~F}_{1}$ and $459 \mathrm{~F}_{2}$ chickens from five full-sib families were genotyped with these markers. The number of total informative meioses per locus varied from 232 to 862 , and the number of phaseknown informative meioses from 0 to 764 . Marker orders in the chromosomes coincided with those of the chicken consensus map, except for markers ADL0147 and MCW0213, on chromosome 13, which were inverted. The reduced number of phase-known informative meioses for ADL0147 (150) may be pointed out as a possible cause for this inversion, apart from the relative short distance between the two markers involved in the inversion $(10.5 \mathrm{cM})$.
\end{abstract}

Key words: Gallus gallus, quantitative trait loci (QTL), genetic maps, microsatellite markers, animal breeding

\section{MAPAS DE LIGAÇÃO DOS CROMOSSOMOS 6, 7, 8, 11 E 13 DE UMA POPULAÇÃO BRASILEIRA DE GALINHA}

RESUMO: O mapa de ligação além de ser fundamental no mapeamento de locos de características quantitativas (QTLs) é importante na organização e localização de genes distribuídos ao longo dos cromossomos. O presente estudo é parte de um trabalho cujo objetivo maior, é a análise de mapeamento de QTLs para características de desempenho no genoma de uma população experimental desenvolvida no Brasil. Com base nesta população foram construídos os mapas de ligação dos cromossomos 6 a 8 , 11 e 13 da galinha. A população foi desenvolvida a partir de duas gerações de cruzamentos entre uma linhagem de corte e uma de postura. Foram testados 51 marcadores microssatélites, dos quais 28 foram informativos: 4, 8, 7, 4 e 5 dos cromossomos 6, 7, 8, 11 e 13, respectivamente. Um SNP localizado no gene do receptor da leptina foi incluído no cromossomo 8 . Os 10 parentais, $8 \mathrm{~F}_{1}$ e um total de 459 aves $\mathrm{F}_{2}$ de cinco famílias de irmãos completos foram genotipados com estes marcadores. $\mathrm{O}$ número de meioses informativas totais por loco variou de 232 a 862 e o de meioses informativas de fase conhecida de 0 a 764. A ordem dos marcadores nos cromossomos coincidiu com a do mapa consenso da galinha, com exceção dos marcadores ADL0147 e MCW0213 do cromossomo 13 que tiveram sua ordem invertida. O número reduzido de meioses informativas de fase conhecida para o marcador ADL0147 (150) pode ser apontado como uma possível causa para a inversão, além da relativa proximidade entre os dois marcadores envolvidos na inversão $(10,5 \mathrm{cM})$.

Palavras-chave: Gallus gallus, locos de características quantitativas (QTLs), mapas genéticos, marcadores microssatélites, melhoramento animal 


\section{INTRODUCTION}

Economically important traits are genetically controlled by many genes, and the genetic linkage map (LM) construction is essential for mapping quantitative trait loci (QTL). Microsatellite markers are commonly used in animal genetic mapping, due to easy amplification by PCR, a high polymorphic degree, and their codominant characteristic (Ferreira \& Grattapaglia, 1998).

Several aspects regarding chickens makes this species extremely well suited to experiments aimed at the localization of QTLs, such as a short generation interval, the ability to generate large full-sib pedigrees, and the ease of obtaining large quantities of DNA from the nucleated blood cell (Groenen et al., 1998). Currently 2,306 loci on 53 linkage groups from a total size of 4,200 cM were identified in chickens (Schmid et al., 2005). Two of three reference populations are actively used for LM: East Lansing (EL) and Wageningen (WAU) (Schmid et al., 2005). However, the first consensus chicken LM (Groenen et al., 2000) was constructed based on these three populations. The first of them, Compton (C), was genotyped with 100 markers on 18 linkage groups, covering $585 \mathrm{cM}$ (Bumstead $\&$ Palyga, 1992). The second map used the EL population and 98 markers in 19 linkage groups, generating a linkage map of $590 \mathrm{cM}$ (Levin et al., 1994). And the last population, WAU, used 430 markers, comprising 28 linkage groups containing 3,062 cM (Groenen et al., 1998). The consensus linkage maps is constantly reviewed and updated, helping as a source for the scientific community.

Our group is conducting the whole chicken genome scanning to identify QTLs in an $\mathrm{F}_{2}$ population generate by crossing a broiler line and a layer line. However, before QTL mapping analyses it is necessary to identify informative markers and construct the LM. A linkage map based on genotyping information from 27 microsatellite markers positioned on chromosomes $6,7,8,11$ and 13 in the intercross is reported here, and will be used for mapping QTL controlling performance and carcass traits.

\section{MATERIALAND METHODS}

\section{Experimental population}

To generate an $\mathrm{F}_{2}$ population, seven males from a broiler line (TT) were mated to seven females from a layer line (CC). Each male was mated to three unrelated females selected randomly to generate $21 \mathrm{~F}_{1}$ families, with approximately 100 chicks per family, in 17 incubations, totalizing 2,063 $\mathrm{F}_{2}$ animals. The construction of the genetic linkage map of chromosomes
$6,7,8,11$ and 13 , used the five informative families indicated in a previous selective genotyping study of chromosomes 1 to 5 in this population (Baron, 2004; Nones et al., 2005; Ruy et al., 2005). TT was selected for various generations for growth related traits, such as body weight, whereas CC was selected for egg production traits (Nones et al., 2006).

\section{DNA isolation}

Animal's blood samples were collected in tubes containing EDTA $10 \%$ and stored in a $-70^{\circ} \mathrm{C}$ freezer. Blood samples were extracted from brachial vein in parents, and through bleeding at slaughter in $\mathrm{F}_{1}$ and $\mathrm{F}_{2}$ animals. Genomic DNA isolation was conducted using the DNAzol ${ }^{\circledR}$ reagent following manufacturer's protocol with minor modifications. DNA concentration in each sample was assessed by spectrophotometer and standardized to a final concentration of $20 \eta \mathrm{g} \mu \mathrm{L}^{-1}$.

\section{Genotyping}

Fluorescent primers were used in PCR to amplify DNA fragments, provided by United States Poultry Genome Project and Roslin Institute, UK. Fragment lengths were determined by the automatic sequencer MEGABace 1000 (GE HealthCare ${ }^{\circledR}$ ). Each PCR sample was prepared using $100 \eta \mathrm{g} \mu \mathrm{L}^{-1}$ of DNA, $4.0 \mathrm{mmol}$ $\mathrm{L}^{-1} \mathrm{MgCl}_{2}, 50 \mathrm{mmol} \mathrm{L}{ }^{-1} \mathrm{KCl}, 10 \mathrm{mmol}$ Tris- $\mathrm{HCl}(\mathrm{pH}$ 8.5), $400 \mu \mathrm{M}$ of each dNTP, 5 U Taq DNA Polymerase and $5 \mathrm{pmol}$ of each primer, totalizing final volume of $25 \mu \mathrm{L}$. The program used in the thermocycler for PCR reactions consisted in an initial denaturation at $95^{\circ} \mathrm{C}$ for 5 minutes, and 30 cycles of: 1 minute at $95^{\circ} \mathrm{C}, 1$ minute at 50 to $67^{\circ} \mathrm{C}$ (annealing temperature) depending on primers sequence, and an extension of 1 minute at $72^{\circ} \mathrm{C}$. After the 30 cycles, an extension at $72^{\circ} \mathrm{C}$ for 10 minutes was conducted.

Three to four markers were combined according to amplicon size and primer fluorescence. Samples were precipitated and ressuspended with $4.75 \mu \mathrm{L}$ loading solution and $0.25 \mu \mathrm{L}$ internal standard ET-ROX400. Genotyping data were checked and corrected manually. A total of 28 markers (out of 51 tested) were used to genotype approximately $459 \mathrm{~F}_{2}$ individuals from five full-sib families, 10 parental and $8 \mathrm{~F}_{1}$ animals on chromosomes $6,7,8,11$ and $13(4,8,7,4$ and 5, respectively) were genotyped.

\section{Linkage analysis}

Genotyping data of the 28 informative markers were used in the linkage analysis, employing the CRIMAP software, version 2.4 (Green et al., 1990), which uses maximum likelihood procedures to estimate recombination fractions and the Kosambi function to convert them to map distances in centiMorgans (cM). 
Initially, the Twopoint option of CRIMAP was used for two-point linkage analysis in which the recombination rate between each of the two most informative linked markers of a chromosome and each one of the other markers was estimated. The order of loci was obtained with the Build option. A pair of highly polymorphic linked loci was chosen to start marker's ordering. The other loci were progressively added to the map, placed in each possible position with respect to the loci already ordered. The best position was based on the highest $\log _{10}$ likelihood and LOD > 3.0 .

The order of different loci was checked using the Flips 2 option, to look for an erroneous order. Finally the Chrompic option was used to verify every combination event amount order markers and to identify errors and potential double-crossing overs. The maps were draw with the MapChart software version 2.1(Voorrips, 2002).

\section{RESULTS AND DISCUSSION}

From 16 markers tested on chromosome 6, 11 could not be used because no amplification products were obtained, and one (ADL0040) was not informative (only one allele). Four markers were used in the construction of the linkage group. On chromosome 7, eight markers were informative, out of 15 tested. Six markers did not generate amplification products, and marker ADL0180 showed only one allele. On chromosome 8, 12 markers were tested, but only seven were informative. The leptin receptor (LEPR) SNP marker identified and genotyped by Ninov et al. (2006) was informative in three full-sib families, presenting two alleles. Chromosomes 11 and 13 counted with four and six markers respectively, and only for MCW0322 on chromosome 13 no amplification products were ob- tained. Table 1 lists all markers used on these five chromosomes and their positions (cM) on the consensus map (Schmid et al., 2005). A total of 28 informative markers were employed on the construction of the linkage maps and the respective number of informative meioses and of phase-known informative meioses are shown on Table 2.

Map distances between markers given in this paper are sex-averaged distances in $\mathrm{cM}$. An initial $\mathrm{LOD}_{\text {score }}=0.0$ was accepted in Twopoint option to estimate the recombination rate between the pairs of markers. Recombination fractions between all markers from each of the five chromosomes were calculated.

The linkage group of chromosome 6 (Figure 1) covered $38 \mathrm{cM}$ out of $146 \mathrm{cM}$ from the consensus map (Schmid et al., 2000), and the average distance between markers was $12.7 \mathrm{cM}$, varying from 2.8 to $20 \mathrm{cM}$. Marker positions on the linkage group were concentrated in the central region, leaving gaps on chromosomes extremities. An effort to increase marker density in gap regions was made, but no informative markers were identified. A larger number of informative markers on these regions would contribute to a complete QTL analysis.

Linkage map of chromosome 7 (Figure 1) had $131.2 \mathrm{cM}$ and average distance of markers was 18.7 $\mathrm{cM}$ (varying from 5.9 to $35.4 \mathrm{cM}$ ). In comparison, the consensus map (Schmid et al., 2000) had $165 \mathrm{cM}$ and 19 fixed position markers were typed. The low information content of marker ADL0107 precluded the inclusion of this marker with a LOD > 3.0. A LOD = 2.0 was accepted to allow linkage between markers ADL0107 (33\% informative meioses phase known compared to total meioses, Table 2) and ADL0279. The markers followed the same order of the consensus map.

Table 1 - Markers selected for linkage map construction of chromosomes 6, 7, 8, 11 and 13.

\begin{tabular}{|c|c|}
\hline Chromosome & Marker (Position cM) \\
\hline 6 & $\begin{array}{l}\text { ADL0323 (0.0); LEI0196 (26.8); MCW0176 (27); *ADL0142 (29); LEI0093 (33.6); *ADL0377 (47); } \\
\text { ADL0138 (55); LEI0092 (67); LEI0097 (74); LEI0212 (80); ADL0040 (82); *MCW0250 (86); ROS0062 } \\
\text { (88); *ROS0003 (91); LEI0192 (115); ABR0323 (146) }\end{array}$ \\
\hline 7 & $\begin{array}{l}* \text { LEI0064 (0.0); *ABR0326 (30); *ADL0107 (51); MCW0201 (79); MCW0183 (86); *ADL0279 (92); } \\
\text { ROS0019 (101); *MCW0236 (109); ADL0180 (109); *ADL0109 (117); LEI0158 (120); MCW0092 (117- } \\
\text { 140); MCW0316(127); *ADL0315 (140);*ADL0169 (175) }\end{array}$ \\
\hline 8 & $\begin{array}{l}\text { *ABR0322 (0.0-14); MCW0305 (15); *MCW0095 (26); ADL0171 (26-27); MCW0100 (40-50); } \\
\text { *ADL0154 (46); *ABR0345 (56); ADL0301 (80); *LEPR (89.6); LEI0136 (70-105); *ADL0172 (80-105); } \\
\text { *MCW0351 (105) }\end{array}$ \\
\hline 11 & *LEI0143 (0.0); *ADL0123 (22); *ADL0210 (54); *MCW0230 (88) \\
\hline 13 & *MCW0213 (22); *ADL0147 (32); *LEI0251 (47); *MCW0110 (59); MCW0322 (67); *MCW0104 (74) \\
\hline
\end{tabular}

*Informative markers 
Table 2 - Informative microsatellite markers used in the linkage analysis, respective number of alleles, number of informative meioses and phase-known informative meioses.

\begin{tabular}{|c|c|c|c|c|}
\hline Marker & GGA & Number of alleles & $\begin{array}{l}\text { Number of informative } \\
\text { meioses }\end{array}$ & $\begin{array}{c}\text { Number of informative meioses } \\
\text { (phase-known) }\end{array}$ \\
\hline ROS0062 & 6 & 03 & 372 & 372 \\
\hline ROS0003 & 6 & 04 & 702 & 702 \\
\hline ADL0377 & 6 & 04 & 269 & 269 \\
\hline ADL0142 & 6 & 04 & 232 & 159 \\
\hline LEI0064 & 7 & 06 & 764 & 764 \\
\hline ABR0326 & 7 & 05 & 862 & 555 \\
\hline ADL0107 & 7 & 02 & 293 & 97 \\
\hline ADL0279 & 7 & 05 & 858 & 360 \\
\hline MCW0236 & 7 & 03 & 451 & 272 \\
\hline ADL0109 & 7 & 03 & 326 & 326 \\
\hline ADL0315 & 7 & 03 & 251 & 251 \\
\hline ADL0169 & 7 & 02 & 357 & 357 \\
\hline ABR0322 & 8 & 04 & 698 & 346 \\
\hline MCW0095 & 8 & 03 & 438 & 438 \\
\hline ADL0154 & 8 & 04 & 700 & 544 \\
\hline ABR0345 & 8 & 04 & 611 & 507 \\
\hline ADL0172 & 8 & 03 & 630 & 428 \\
\hline MCW0351 & 8 & 03 & 345 & 241 \\
\hline LEPR & 8 & 02 & 396 & 0 \\
\hline LEI0143 & 11 & 03 & 463 & 325 \\
\hline ADL0123 & 11 & 04 & 620 & 620 \\
\hline ADL0210 & 11 & 04 & 478 & 478 \\
\hline MCW0230 & 11 & 04 & 608 & 432 \\
\hline ADL1047 & 13 & 03 & 307 & 150 \\
\hline MCW0213 & 13 & 06 & 606 & 606 \\
\hline LEI0251 & 13 & 05 & 602 & 430 \\
\hline MCW0110 & 13 & 05 & 612 & 612 \\
\hline MCW0104 & 13 & 05 & 626 & 446 \\
\hline
\end{tabular}

Means of total and phase-known informative meioses of chromosome 8 were 545 and 358 , respectively. Three out of seven markers are fixed in the consensus map and followed the same order of the consensus map (ADL0154, ABR0345 e MCW0351). The number of phase known informative meioses for MCW0095 (not fixed) was 100\%. The remaining markers showed variation from $68 \%$ to $83 \%$ for phase known informative meioses compared to total meioses, with the exception of marker ABR0322 that showed $49.6 \%$.

The average marker interval on chromosome 8 was $14.9 \mathrm{cM}$ (Figure 1), varying between 0.5 and $40.3 \mathrm{cM}$, and the total length was $89.6 \mathrm{cM}$. The largest gap was between markers ABR0345 and ADL0172.

Linkage map of chromosome 11 (Figure 1) was in good agreement with the consensus linkage map, showed the same marker order and a total length of $105.5 \mathrm{cM}$. The average distance between adjacent markers was $35.2 \mathrm{cM}$. The consensus map length was $88 \mathrm{cM}$. Differences in length could be explained by the use of different population crosses and number of markers (four were used in the present study, comparing to nine on the consensus map). These factors result in different estimates of recombination rates that contribute to map divergences.

The linkage map of chromosome 13 showed $57 \mathrm{cM}$, whereas the consensus map had $74 \mathrm{cM}$. An inversion of marker positions occurred between markers ADL0147 and MCW0213. In the study by Jennen et al. (2004) the linkage map for chromosome $13 \mathrm{had}$ $54.8 \mathrm{cM}$ and the first and last markers were MCW0104 and MCW0213, similar to this study. 

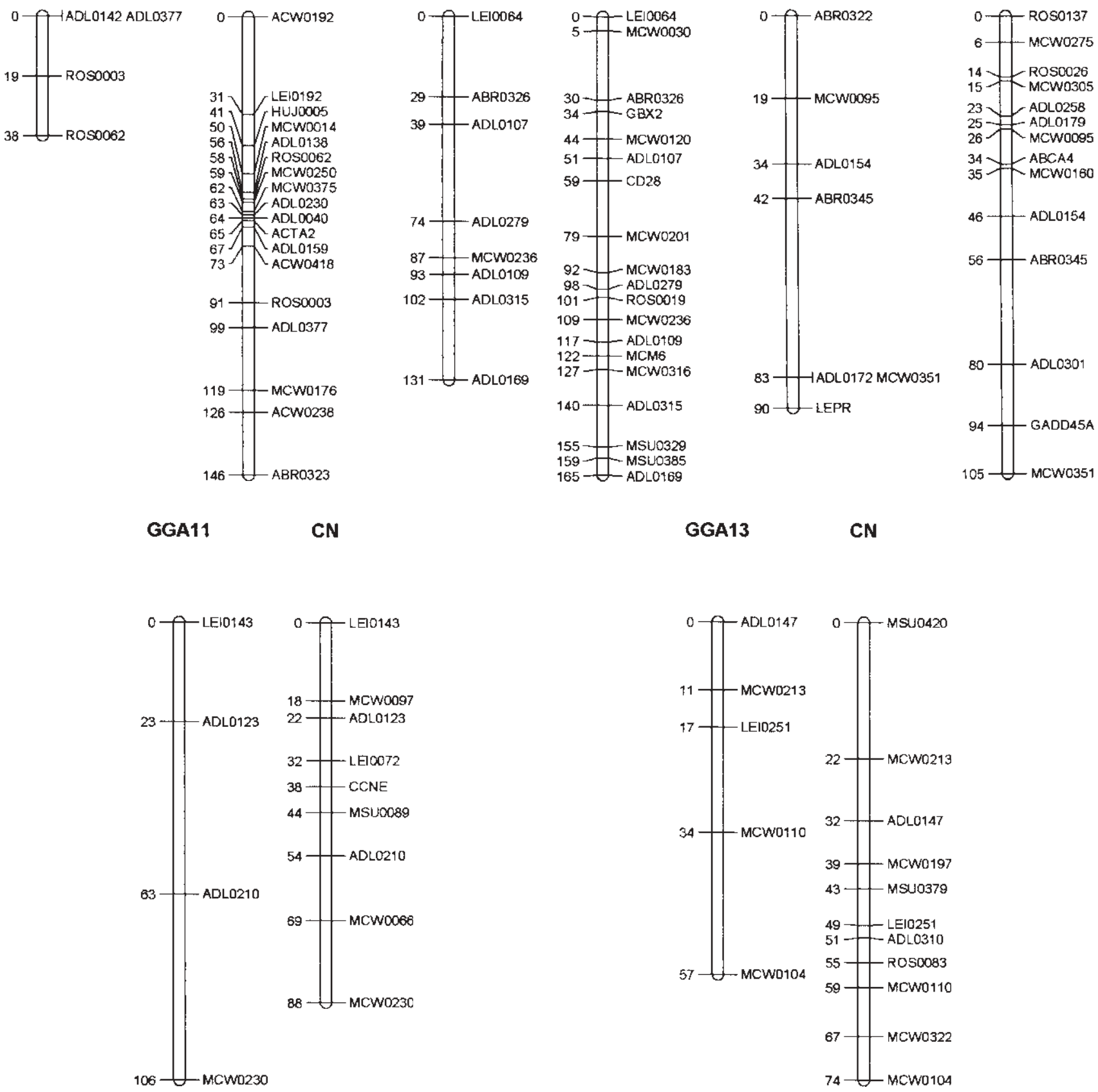

Figure 1 - Linkage group of chromosome 6 and linkage maps of chromosomes 7, 8, 11 and 13, and their updated linkage consensus maps (Schmid et al., 2000).

Marker ADL0147, involved in the order inversion, presented a low number of phase known informative meioses compared to other markers (Table 2). This can make it difficult to determine the order of the marker in the linkage map. Nevertheless, the other marker involved in the order inversion (MCW0213) was highly informative. Additionally, the interval between these two markers was small (10.5 $\mathrm{cM}$ ), which may have caused difficulties in determin- ing the relative position of these two markers in the linkage map.

Linkage maps were generated using a high number of $\mathrm{F}_{2}$ animals from the experimental population, resulting in an average number of 517 informative meioses. In WAU resource population maps, the average was 400 for 10 half-sib families with approximately $46 \mathrm{~F}_{2}$ animals per family (Groenen et al., 1998). The EL and $\mathrm{C}$ resource population maps (52 and 56 
backcrosses) showed even lower number of informative meioses, varying from 20 to 50, respectively. Therefore, the resource population used in this study provided a high number of informative meioses, generating reliable linkage maps for QTL mapping. The average numbers of informative meioses and of phaseknown informative meioses of each chromosome (6, $7,8,11$ and 13) were: 393.7 and $375.5 ; 520.2$ and $372.8 ; 545.4$ and $357.7 ; 542.2$ and $463.7 ; 550.6$ and 448.8 , respectively. The addition of microsatellite markers, especially in the intervals that exceeded $20 \mathrm{cM}$, would greatly aid in the saturation and utility of this genetic map for QTL mapping.

\section{CONCLUSIONS}

The procedures used on linkage map construction for this resource population showed valuable results when compared with data from the chicken consensus map. Average numbers of informative meioses were high, indicating that results were reliable.

\section{ACKNOWLEDGEMENTS}

The current study was funded by Embrapa/ PRODETAB and Fapesp (Fundação de Amparo à Pesquisa do Estado de São Paulo) that has also granted scholarships to Marcel Ambo, R.L.R. Campos, C. Boschiero, K. Nones and M.F. do Rosário. A scholarship from CNPq was granted to A.S.A.M.T. Moura. L.L. Coutinho is a recipient of a research productivity scholarship from CNPq.

\section{REFERENCES}

BARON, E.E. Identificação de QTLs nos cromossomos 2 e 4 que controlam características de desempenho e carcaça em aves (Gallus gallus). Piracicaba: USP/ESALQ, 2004. 96p. Tese (Doutorado)

BUMSTEAD, N.; PALYGA, J. A preliminary linkage map of the chicken genome. Genomics, v.13, p.690-697, 1992.

FERREIRA, M.E.; GRATTAPAGLIA, D. Introdução ao uso de marcadores em análise genética. 3 ed. Brasília: CENARGEN, 1998. 220p.

GREEN, P.; FALLS, K.; CROOKS, S. CRI-MAP Program version 2.4. St. Louis: Washington University School of Medicine, 1990.

GROENEN, M.A.M.; CROOIJMANS, R.P.M.A.; VEENENDAAL, A.; CHENG, H.H.; SIWEK, M.; POEL, J.J. van der A comprehensive microsatellite linkage map of the chicken genome. Genomics, v.49, p.265-274, 1998.

GROENEN, M.A.M; CHENG, H.H.; BUMSTEAD, N.; BENKEL, B.F.; BRILES, W.E.; BURKE, T.; BURT, D.W.; CRITTENDEN, L.B.; DODGSON, J.; HILLEL, J.; LAMONT, S.J.; LEON, A.P.; SOLLER, M.; TAKAHASHI, H.; VIGNAL, A. A consensus linkage map of the chicken genome. Genome Research, v.10, p.137-147, 2000
JENNEN, D.G.J.; VEREIJKEN, A.L.J.; BOVENHUIS, H.; CROOIJMANS, R.P.M.A.; VEENENDAAL, A.; POEL, J.J. van der; GROENEN, M.A.M. Detection and localization of quantitative trait loci affecting fatness in broilers. Poultry Science, v.83, p.295-301, 2004.

LEVIN, I.; SANTANGELO L.; CHENG, H.; CRITTENDEN, L. B.; DODGSON, J.B.; An autosomal genetic linkage map of the chicken. Journal of Heredity, v.85, p.79-85, 1994.

NINOV, K.; LEDUR, M.C.; NONES, K.; CAETANO, A.R.; COLDEBEllA, A.; BERTOL, T.M.; COUTINHO, L.L. Mining of polymorphisms in the leptin receptor gene in two chicken lines and their association with performance and carcass traits. In: INTERNATIONAL CONFERENCE ON ANIMAL GENETICS, 30., Porto Seguro, 2006. Proceedings. Belo Horizonte: CBRA, 2006. CD-ROM.

NONES, K.; LEDUR, M.C.; RUY, D.C.; BARON, E.E.; MOURA, A.S.A.M.T.; COUTINHO, L.L. Genetic linkage map of chicken chromosome 1 from a Brazilian resource population. Scientia Agricola, v.62, p.12-17, 2005.

NONES, K.; LEDUR, M. C.; RUY, D.C.; BARON, E.E.; MELO, C.M.R.; MOURA, A. S.A.M.T.; ZANELLA, E.L.; BURT, D.W.; COUTINHO, L.L. Mapping QTLs on chicken chromosome 1 for performance and carcass traits in a broiler $\mathrm{x}$ layer cross. Animal Genetics, v.37, p.95-100, 2006.

RUY, D.C. NONES, K.; BARON, E.E.; LEDUR, M.C.; MELO, C.M.R.; AMBO, M.; CAMPOS, R.L.R.; COUTINHO, L.L. Strategic marker selection to detect quantitative trait loci in chicken. Scientia Agricola, v.62, p.111-116, 2005.

SCHMID, M.; NANDA, I.; GUTTENBACH, M.; STEINLEIN, C.; HOEHN, H.; SCHARTL, M.; HAAF, T.; WEIGEND, S.; FRIES, R.; BUERSTEDDE, J-M.; WIMMERS, K.; BURT, D.W.; SMITH, J.; A'HARA, S.; LAW, A.; GRIFFIN, D.K.; BUMSTEAD, N.; KAUFMAN, J.; THOMPSON, P.A.; BURKE, T.A.; GROENEN, M.A.M.; CROOIJMANS, R.P.M.A.; VIGNAL, A.; FILLON, V.; MORRISON, M.; PITEL, F.; TIXIER-BOICHARD, M.; LADJALI-MOHAMMEDI, K.; HILLEL, J.; MAKI-TANILA, A.; CHENG, H.H.; DELANY, M.E.; BURNSIDE, J.; MIZUNO, S. First report on chicken genes and chromosomes 2000 . Cytogenetics and Cell Genetics, v.90, p.169-218, 2000.

SCHMID, M.; NANDA, I.; HOEHN, H.; SCHARTL, M.; HAAF, T.; BUERSTEDDE, J.M.; ARAKAWA, H.; CALDWELL, R.B.; WEIGEND, S.; BURT, D.W.; SMITH, J.; GRIFFIN, D.K.; MASABANDA, J.S.; GROENEN, M.A.; CROOIJMANS, R. P.; VIGNAL, A.; FILLON, V.; MORISSON, M.; PITEL, F.; VIGNOLES, M.; GARRIGUES, A.; GELLIN, J.; RODIONOV, A.V.; GALKINA, S.A.; LUKINA, N.A.; BEN-ARI, G.; BLUM, S.; HILLEL, J.; TWITO, T.; LAVI, U.; DAVID, L.; FELDMAN, M.W.; DELANY, M.E.; CONLEY, C.A.; FOWLER, V.M.; HEDGES, S.B.; GODBOUT, R.; KATYAL, S.; SMITH, C.; HUDSON, Q.; SINCLAIR, A.; MIZUNO, S. Second report on chicken genes and chromosomes 2005. Cytogenetic and Genome Research, v.109, p.415-479, 2005.

VOORRIPS, R.E. MapChart: software for the graphical presentation of linkage maps and QTLs. The Journal of Heredity, v.93, p.77-78, 2002 .

Received July 26, 2007

Accepted February 15, 2008 